\title{
Inhibition of Protein Tyrosine Phosphatase 1B by Aurintricarboxylic Acid and Methylenedisalicylic Acid; Polymer versus Monomer
}

\author{
Suja Shrestha, Keun-Hyeung Lee, and Hyeongin Cho ${ }^{*}$ \\ Department of Chemistry and Institute of Molecular Cell Biologw, Inha Chiversit, \\ Ionghyn-dong, Nam-ku, Incheon $+02-751$, Korea \\ Received June 5, 2004
}

Key Words : Protein țrosine phosphatase. Aurintricarboș̣lic acid. Metlyylenedisaliç̣lic acid. PTPIB. Inhibitor

Aurintricarboxylic acid (ATA) is a substance that has been known to prevent apoptotic cell death in numerous cell types. ${ }^{1-4}$ ATA is also known to exhibit inhibitory activity against a broad range of enzymes and this property has been utilized in many biological experiments. ${ }^{5-7}$ ATA is represented in many of the literature as a chenical containing three salicylic acid moieties (1. 2). ${ }^{8}$ Commercial ATA. hovever. contains significant anounts of polymeric materials schematically represented as 3 . In general. ATA is prepared by condensation of salicylic acid with formaldehyde and the branching reaction results in the formation of polymers of molecular weights up to several thousands Dalton. ${ }^{9.12}$<smiles>O=C(O)C1=CC(=C(c2ccc(O)c(C(=O)O)c2)c2ccc(O)c(C(=O)O)c2)C=CC1=O</smiles>

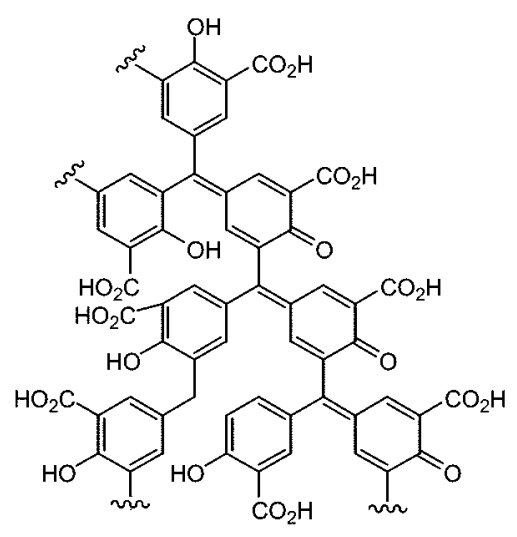

3

high molecular weight components. Not to mention conmercial ATA, the ATA sample synthesized according to the method $^{8}$ (method A. Scheme 1) previously reported to produce monomer was also found to contain polymeric materials as described below. Therefore. monomeric component of ATA (2) was prepared absolutely free of polymer. Also synthesized in a pure form was methỵlenedisalicylic acid (MDSA). one of the low molecular weight components fomed in the conventional preparation of ATA. Commercial MDSA was also proved to contain polymeric substances. The inlibitory potency of ATA and MDSA synthesized in a polymer-free form was evaluated against human protein tyrosine phosphatase lB (PTPIB).

Dimethyl methylenedisalicylate (5) was prepared by the reaction of methyl salicylate and trioxane according to the reported procedure (Scheme 1) ${ }^{16}$ It was purified by column cluromatography to remove any unwanted by-products containing more than two salicylic acid moieties and then hydrolyzed to obtain polymer-free $\operatorname{MDSA}(\boldsymbol{6})$. Carbinols 2a2d were synthesized from MDSA or its dimethyl ester in four independent routes. They are basically the same compound containing different amounts of polymeric byproducts. In methods $\mathrm{B}$ and $\mathrm{C}, \mathbf{2} \mathbf{a}$ was esterified. purified and hydrolyzed to obtain $\mathbf{2 b}$ and $\mathbf{2 c}$. Another strategy (method D) was to condense 4 and 5 . The resulting triester was columm-purified and hydrolyzed to obtain $2 \mathbf{d}$.

We evaluated the inhibitory potency of the synthesized carbinol samples 2a-2d. Samples $2 a-2 d\left(\mathrm{IC}_{50}=18-120 \mu \mathrm{M}\right.$ ) were significantly less potent compared to the commercial ATA ( $\mathrm{IC}_{51}=0.5 \mu \mathrm{M}$ ) indicating that high molecular weight components of commercial ATA are more effective inlhibitors of PTPIB. Among $\mathbf{2 a - 2 d}, \mathbf{2 a}$ was $>4$-fold more potent compared to $\mathbf{2 b - 2 d}$. This is probably due to the differences in the contents of the contaminating polymeric substances, because the polymeric by-products were removed during the syntheses of $\mathbf{2 b} \mathbf{b} \mathbf{2} \mathbf{d}$ but not for synthesis of $\mathbf{2 a}$. Even though method A was developed previously to obtain monomeric ATA, this method was not absolutely free from polymer formation and the contaminants played major role in the inhibition of PTPIB. Considering that the IC $\mathrm{S}_{50}$ values of commercial ATA and 2d were $0.5 \mu \mathrm{M}$ versus $120 \mu \mathrm{M}$, a 240-fold difference. sample $2 \mathrm{~d}$ mixed with just a few percent of commercial ATA would exhibit $\mathrm{IC}_{50}$ value much lower than $120 \mu \mathrm{M}$. Commercial sample of MDSA was also

activity of ATA against PTPases resides in the monomer or 
Table 1. Inhibition of PTPIB by methylenedisalicylic acid (6) and 3,3',3"Tricarboxy-4,4',4"-trihydroxytripheny lcarbinol (2a-2d) samples prepared in four different strateges

\begin{tabular}{|c|c|c|c|c|c|c|c|}
\hline & Commercial $2^{b}$ & $2 a^{r}$ & $2 \mathbf{b}^{r}$ & $2 \mathrm{c}^{r}$ & $2 d^{c}$ & Commercial $6^{b}$ & 6 \\
\hline $\mathrm{IC}_{\mathrm{s0}_{0}}(\mu \mathrm{M})^{a}$ & $0.50 \pm 0.14$ & $18 \pm 2$ & $89 \pm 18$ & $93 \pm 8$ & $120 \pm 15$ & $20 \pm 11$ & $3600 \pm 790$ \\
\hline
\end{tabular}

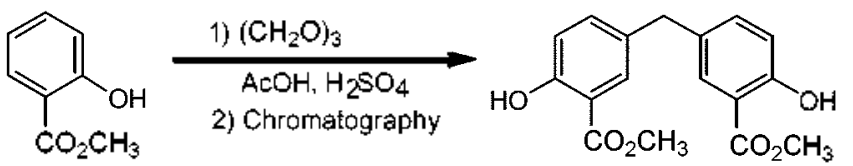

5<smiles>CC(C)C(=O)O</smiles>

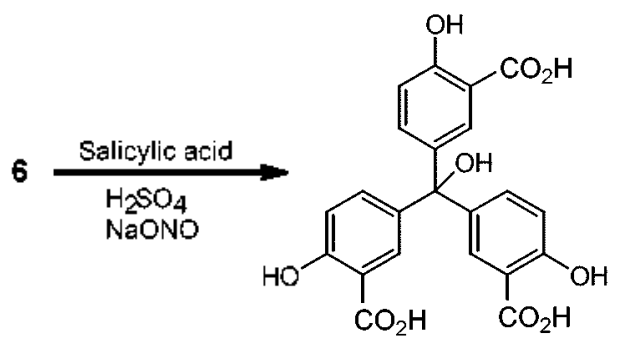

$2 a$

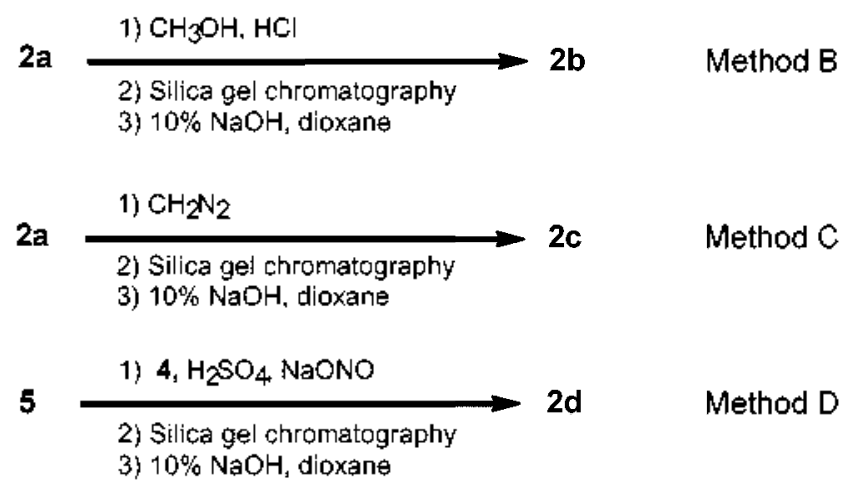

Scheme 1. Synthetic strategies for the syntheses of methylenedisalicylic acid (6) and $3,3^{\prime}, 3^{\prime \prime}$-tricarboxy-4,4, $4^{\prime \prime}$-trihydrosytriphenylcarbinol (2a-2d) in four different routes.

recognized to contain polymeric materials that might deceive experimental results. As shown in Table 1. commercial sample exhibited $\mathrm{IC}_{50}$ of $20 \mu \mathrm{M}$, a 180 -fold lower value than that of polymer-free MDSA.

ATA is listed as an apoptosis inhibitor in catalogs of commercial providers including Oncogene Research Products (Darmstadt. Germany). To the best of our knowledge. most. if not all. of the experiments utilizing ATA as an apoptosis blocker have used conmercial ATA ${ }^{1,2, t}$ The latter. however, is not a homogeneous substance. ATA synthesized according to a commonly used procedure had previously been fractionated to a mixture of more than twenty substances in a broad molecular weight range. ${ }^{y-12}$ Even though each of the components are not completely characterized. the structure of the polymeric substances are generally described as $3{ }^{9}$ It is not evident at this stage whether the anti-apoptotic effect of ATA resides in the monomeric form or in high molecular weight components. However, if the effect of ATA is directly related with its inhibitory activity against PTPases as recently proposed by us. ${ }^{15}$ polymeric components are likely to be more active ingredients.

Acknowledgement. This work was supported by research grant from Inha University (2004).

\section{References}

1. Batistatou, A.: Greene. L. A. J. Cell Biol 1991. 115. 461.

2. Batistatou. A.: Greene. L. A. J. Cell Biol. 1993. 122. 523.

3. Tsi. C.-J: Chao. Y.: Chen. C.-W. Lin. W.W. Mol Phomacol. 2002. 101. 90

4. Haimsohn. M.: Beery, R.: Karasik, A.; Kanety: H.: Geiger, A. Endocrinolog, $2002,1+3,837$.

5. Seki. S.; Tsutsui. K: Oda. T. Biochem. Biophys. Res. Conmun. 1977. 79.179

6. Givens. J. F.: Manly. K. F. Nucleic Acids Res 1976. 3. 405.

7. Catchpoole. D. R.: Stewait. B. W. Anticancer Res. 1994. It. 853.

8. Cushman, M; Kanamathareddy. S. Tetohedron 1990. 46. 1491.

9. Cushman. M.: Wang. P.: Stowell. J. G.: Schols. D.: Clerç. E. D. J. Org Chem. 1992.57.7241.

10. Cushman. M.: Kanamathareddy: S.: Clereq. E. D.: Schols. D: Goldmant. M. E.: Bowen. T. A. J. Hed. Chent 1991. 34. 337.

11. Wang, P., Kozlowski, J.: Cushman. M. J. Org. Chent 1992. 57. 3861 .

12. Weinstein. M.; Vosburgh. E; Philips, M.: Tumer, N.: Chute-Rose. L.: Moake. T. Blood 1991. 78. 2291 .

13. Liang. F.: Huang. Z.: Lee. S.-Y.: Liang. T.: Ivanov. M. I.: Alonso. A.: Bliska. T. B.: Lawrence. D. S.: Mustelin. T.: Zhang. Z.-Y. $J$. Biol. Chem. 2003, 278. 41734 .

14. Beery, R.: Haimsohn. M:- Wertheim. N.: Hemi. R.: Nir, U.: Karasik, A.; Kanety, $\mathrm{H} ;$ Geiger, A. Endocrinolog, 2001. 142, 3098.

15. Cho. H.: Lee. D. Y.: Shrestha. S.: Shim. Y. S.: Kim. K. C.: Kim. M.-K.: Lee. K.-H.: Won. J.: Kang. T-S. Mol. Cells 2004. 18. 46.

16. Smith. W. H.: Sager. E. E.: Siewer. I. J. Anal. Chent 1949, 21. 1334.

17. Shim. Y. S.; Kim. K. C.; Chi, D. Y; Lee, K.-H.; Cho, H. Bioorg. 1ed. Chem. Lett. 2003. 13. 2561 